\section{||||||||||||||||||||||||||||||||||||||||||||||||||||||||}

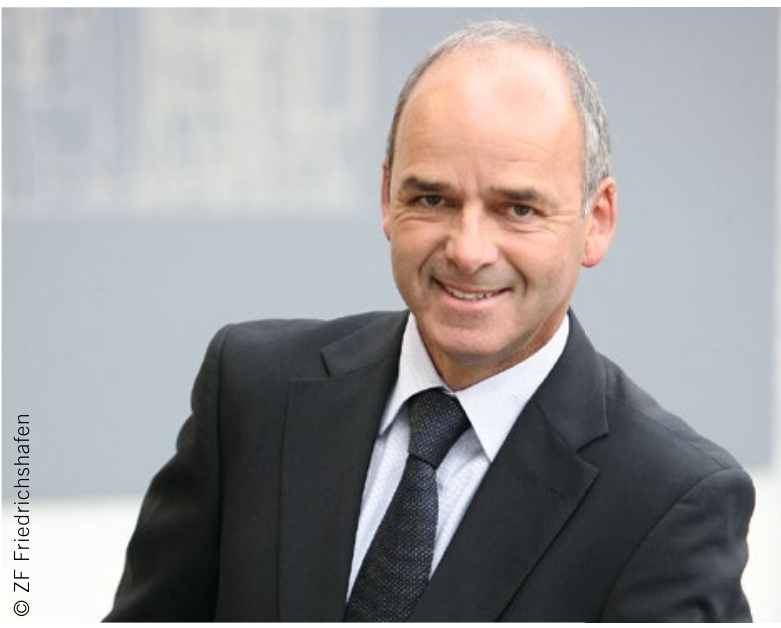

Hermann Beck Executive Vice President Industrietechnik und Arbeits maschinensysteme bei ZF Friedrichshafen in Passau

Hermann Beck Executive Vice President Industrial Technology and Off-Highway Systems at ZF Friedrichshafen in Passau (Germany)

\title{
Stufenlos in die Zukunft
}

Verknappung der Ressourcen, steigende Marktanforderungen und gesetzliche Bestimmungen wie Tier 4 final zwingen die Baumaschinenindustrie weltweit zum Umdenken. Forderungen nach optimiertem Kraftstoffeinsatz, höherer Effizienz und Kostenreduzierung setzen die Trends in der Arbeitsmaschinenbranche. Global agierende Unternehmen wie ZF benötigen bei derlei unterschiedlichen Anforderungen die passende Antriebstechnologie je nach Produktund Marktstrategie des Kunden.

Ein Trend zu niedrigeren Motordrehzahlen und der Wunsch nach Motorberuhigung durch ein Konstantdrehzahlkonzept sind die zukünftigen Herausforderungen im Markt. ZF setzt hier auf Stufenlostechnologie, um beide Vorgaben erfüllen zu können. Hohe Lasten bei geringen Geschwindigkeiten in Kombination mit hoher Dynamik sind die besonderen Anforderungen in der Arbeitsmaschine. Genau diese Kriterien werden von der CVT-Getriebetechnologie bei einem bisher nicht denkbar gewesenem Wirkungsgradniveau optimal erfüllt.

Mit hydrostatisch-mechanisch leistungsverzweigten Getrieben können im Bau- und Forstmaschinenbereich deutliche Verbrauchsvorteile bei gleichzeitiger Performancesteigerung im Vergleich zu hydrodynamischen Getrieben und rein hydrostatischen Konzepten erzielt werden. Auch bei geringer Geschwindigkeit und Arbeitseinsätzen mit hohem Drehmoment, wie beispielsweise dem Beladen der Schaufel, wird ein hervorragender Effizienzgrad erzielt. Darüber hinaus liefern CVT-Systeme auch bei hohen Geschwindigkeiten dieselbe Performance wie Wandlergetriebe mit geschlossener Wandlerkupplung.

\section{Continuously Variable into the Future}

Resource shortages, rising market requirements and legal provisions like Tier 4 final force the construction machinery industry all over the world to rethink. Demands for optimised fuel usage, higher efficiency and cost reduction are setting the trend in the off-highway systems sector. In view of such different requirements, global companies like ZF, need the suitable drive technology depending on product- and market strategies.

A tendency towards lower engine speeds and the demand for engine stabilisation by a constant speed concept are the future challenges on the market. ZF trusts in a continuously variable technology to meet both requirements. High loads at low speeds combined with high dynamics are special demands in the off-road machinery. And these criteria are exactly what the CVT transmission technology optimally fulfils with a degree of efficiency which has so far been unthinkable.

In the construction and forestry sector, hydrostatic-mechanically power-split transmissions offer considerable consumption benefits with concurrent higher performance over hydrodynamic transmissions and completely hydrostatic concepts. Excellent efficiency is achieved even in low speed and high torque operation such as bucket filling. Additionally CVT systems reach the same performance at high speed like torque converter transmissions with closed lock up clutch. 